\title{
UMBATRA
}

Indonesian Journal of Anthropology

Volume 6 (2) Desember 2021 || eISSN 2528-1569 | pISSN 2528-2115 || http://jurnal.unpad.ac.id/umbara

DOI : 10.24198/umbara.v6i2.35903

\section{Perjuangan Pengakuan Hak Kelola Lahan bagi Pengungsi Aceh di Kawasan Taman Nasional Gunung Leuser}

\author{
Doni Latuparisa ${ }^{1}$, Suraya Abdulwahab Afiff ${ }^{2}$ \\ ${ }^{1}$ Pascasarjana Antropologi, Fakultas Ilmu Sosial dan Politik, Universitas Indonesia \\ doni.latuparisa@ui.ac.id \\ ${ }^{2}$ Departemen Antropologi, Fakultas Ilmu Sosial dan Politik, Universitas Indonesia \\ suraya.afiff@ui.ac.id
}

\begin{abstract}
Gunung Leuser national park covers an area of 830,268.95 hectares which has been designated as a national park since 1980. It has been managed by the Indonesian government through Gunung Leuser National Park Center. Ecological zonation systems have been implemented in the management. However, since about 1999, groups of refugees who escaped from the Aceh conflict have resided in the national park. They transformed the dry or bush landscape which is designated for conservation area into settlements, as well as rubber and oil palm plantations. The national park authority considers their activities illegal. While the refugees, after 20 years of their activities in the park, consider themselves to have the rights to cultivate the land. They have attempted various ways to legalize their settlement and right to cultivate the area inside the park. This qualitative study aims at describing the tenurial conflict faced by refugees residing in the Gunung Leuser national park. Data were collected through interviews and participant observation. The study found the violence and harsh tension in regards to this tenurial conflict. On one hand, the refugees fight for their livelihood in the park. On the other hand, the park management tends to implement their authority to assure the original function of the national park. The government should take necessary action to resolve this long-term conflict using a rights-based approach; so the refugees, who are also the citizens of the state, could have their access to cultivate the land.
\end{abstract}

Keywords: conflict, agrarian, tenure, territorialization

\begin{abstract}
Abstrak
Taman Nasional Gunung Leuser adalah kawasan seluas 830.268,95 ha yang ditetapkan pemerintah RI sebagai Taman Nasional pada 1980. Kawasan ini memiliki ekosistem asli dan menjadi tempat pelestarian alam yang dikelola dengan sistem zonasi. Kawasan ini merupakan milik negara dan pengelolaannya dilakukan oleh Balai Besar Taman Nasional Gunung Leuser. Pada sekitar 1999, rombongan keluarga korban konflik politik Aceh yang sebagian besar adalah imigran dari Jawa mengungsi ke wilayah TNGL pasca pemberlakuan Aceh sebagai Daerah Operasi Militer. Kehadiran pengungsi sebanyak 708 kepala keluarga di kawasan ini telah mengubah lanskap gergas atau semak belukar menjadi pemukiman, kebun karet, dan kebun sawit. Kehadiran mereka di TNGL dianggap ilegal dan bertentangan dengan tujuan taman nasional. Mereka dianggap merambah, karena tidak pernah memiliki izin resmi pengelolaan lahan di kawasan taman nasional. Setelah 20 tahun mendiami kawasan TNGL, para pengungsi melakukan berbagai upaya mendapatkan legalitas atas lahan garapan mereka. Namun, upaya itu masih belum berhasil. Penelitian kualitatif ini bertujuan memaparkan konflik tenurial yang dialami para pengungsi Aceh di
\end{abstract}


TNGL. Data dikumpulkan dari hasil observasi dan wawancara. Hasil penelitian ini menunjukkan adanya dinamika dalam konflik penguasaan kawasan TNGL. Ragam bentuk kekerasan dan penyingkiran terhadap pengungsi Aceh terjadi karena mereka dianggap tidak memiliki hak untuk mengakses kawasan TNGL. Di satu sisi, para pengungsi berupaya mempertahankan hak atas mata pencaharian mereka. Di sisi lain, pengelola TNGL berusaha mempertahankan wilayah teritorinya dan menjaga kedaulatan kawasan Taman Nasional. Fenomena konflik dan resolusi konflik antara pengungsi dan pengelola TNGL serta beberapa kelompok lokal yang terlibat, seharusnya pemerintah menggunakan pendekatan berbasis hak.

Kata kunci: konflik, agraria, kepemilikan, teritorialisasi

\section{Pendahuluan}

Permasalahan kepemilikan lahan merupakan manifestasi dari kekuatan politik dan ekonomi terkait dengan penyebarluasan kapitalisme sejak abad ke-19 (Robbins, 2008). Di Indonesia, sejak masa Orde Baru hingga kini, sudah banyak kisah tumpang tindih terkait klaim negara dan masyarakat yang tinggal di areal kawasan hutan Indonesia. Konflik agraria seringkali terjadi ketika masyarakat yang memiliki mata pencaharian di suatu kawasan harus berhadapan dengan permasalahan dan perlindungan lingkungan di kawasan tersebut. Hal ini terjadi di wilayah Indonesia terutama di kawasan hutan yang sebagian kawasannya masih dimanfaatkan masyarakat sebagai sumber penghidupan.

Kasus konflik tenurial di dalam dan sekitar hutan umumnya memiliki pola perampasan hak pengelolaan masyarakat adat, masyarakat lokal atau petani dan penggarap. Sementara itu, pemerintah justru memberikan izin kepada pihak ketiga di "hutan negara" yang belum diverifikasi (Tim Inkuiri Nasional Komnas HAM, 2016). Kebijakan yang kontradiktif dan standar ganda ini menyebabkan konflik pengelolaan sumber daya alam dan agraria semakin bertambah selaras dengan pelanggaran hak asasi manusia.

Direktorat Penanganan Konflik Tenurial dan Hutan Adat (PKTHA) sampai tahun 2017 telah mengidentifikasi 195 kasus konflik yang dipicu oleh absennya masyarakat dalam proses tenurial (Kaputra et al., 2015). Masyarakat justru dianggap sebagai perambah oleh negara karena memanfaatkan hasil hutan. Pemanfaatan hutan oleh masyarakat tidak dapat dihindarkan. Berdasarkan data Badan Pusat
Statistik (BPS) tahun 2007-2009, terdapat 31.957 desa yang berada di dalam dan sekitar kawasan hutan. Dari jumlah tersebut, 71,06 \% menggantungkan hidup pada kawasan hutan (Nuraini et al., 2016).

Beberapa penelitian terkait konflik dalam isu agraria ini pernah dilakukan. Misal penelitian tentang konflik komunitas petani Paluh Merbau di Percut (Darmawan et al., 2020). Konflik antara masyarakat Desa Ranupani dengan otoritas Taman Nasional Bromo Tengger Semeru (Hekmatyar et al., 2021). Sengketa petani dengan pemerintah akibat pembangunan Bandar Udara Kuala Namu (Kaputra et al., 2020). Ketidakjelasan status lahan masyarakat Desa Margosari (Harnadi, 2019). Berdasarkan penelitian diatas, tampak jelas bahwa konflik agraria yang terjadi di beberapa bagian wilayah Indonesia masih menjadi polemik yang menunggu untuk segera diatasi oleh pemerintah.

Penelitian ini membahas konflik agraria tentang hak penguasaan lahan, antara pengungsi Aceh yang mendiami Taman Nasional Gunung Leuser (TNGL) dengan pemerintah. Pengungsi Aceh yang tinggal di kawasan ini merupakan korban dari konflik bersenjata antara Militer Indonesia dengan Gerakan Aceh Merdeka (GAM).

Menilik dari sejarah yang ada, para pengungsi Aceh tersebut adalah migran asal Jawa. Mereka sudah masuk ke negara bagian Sumatera Timur sejak 1863, setelah Jacobus Neinhuys mendirikan onderneming asing untuk pertama kalinya di wilayah ini. Selama 22 tahun, telah berdiri 148 onderneming asing yang melakukan perluasan perkebunan dengan menanam tembakau, 
karet, dan kelapa sawit untuk memenuhi permintaan pasar internasional. Pelzer (1985) mengungkap kebutuhan tenaga kerja secara besar-besaran menjadi sebab didatangkannya tenaga kerja ke Sumatera timur, termasuk dari Jawa. Sekitar 140.000 tenaga kerja dikumpulkan ke wilayah perkebunan sejak abad 18 hingga tahun 1915. Hal inilah yang menjadi awal mula anak keturunan buruh kontrak asal Jawa mulai migrasi ke Aceh. Mereka menyebut aktivitas migrasi ini dengan merantau. Saat itu area hutan masih banyak yang bisa dibuka di wilayah ini.

Pada 1976, terjadi perlawanan di Aceh akibat kekecewaan sekelompok masyarakat yang merasa sumber daya alam di Aceh di eksploitasi tanpa distribusi yang adil antara pemerintah Indonesia dan Aceh. Perlawanan masyarakat ini dikenal dengan Gerakan Aceh Merdeka (GAM) (Zainal, 2016). Kondisi ini menyebabkan para perantau yang semula tinggal di Aceh, terpaksa keluar dari Aceh dan mengungsi di lokasi-lokasi yang lebih aman. Pemerintah Indonesia juga terpaksa untuk mendeklarasikan bahwa Aceh masuk ke dalam Daerah Operasi Militer (DOM). Implikasi dari kebijakan ini adalah selain warga Aceh tidak dapat memasuki daerah tersebut (Sudirman et al., 2018). Situasi akibat kebijakan ini membuat posisi migran asal Jawa di Aceh terdesak terpaksa mengungsi ke daerah lain. Sejak akhir tahun 1999, sebanyak 15 Kepala Keluarga (KK) pengungsi Aceh bergerak menyelamatkan diri menuju wilayah kawasan TNGL. Pada saat penelitian ini dilakukan di 2020, terdapat sejumlah 708 kepala keluarga berdiam di kawasan ini. Para pengungsi ini menempati dan menggarap lahan seluas 6.700 ha di kawasan TNGL, tanpa izin resmi dari pengelola taman nasional.

Taman nasional, TNGL berfungsi sebagai kawasan konservasi dengan sistem zonasi. Area yang ditempati pengungsi seharusnya merupakan adalah Zona Inti yang kemudian diubah statusnya menjadi Zona Khusus. Para pengungsi ini tidak memiliki hak resmi atas wilayah yang mereka tempati dan kelola sehingga mereka ini dianggap sebagai "pe- rambah" oleh pemerintah, dalam hal ini Balai Besar Taman Nasional Gunung Leuser (BBTNGL) selaku pengelola.

Pada Februari 2018, dalam acara Kongres Petani yang dihadiri BB-TNGL dan Pemerintah Daerah Kabupaten Langkat, dilakukan penandatanganan Memorandum of Understanding (MoU) yang berisi peningkatan fungsi TNGL. Hal ini makin mengancam status pengungsi yang tinggal di dalam kawasan TNGL. Situasi ini merefleksikan apa yang dibahas Robbins (2019) bahwa konflik tenurial bisa terjadi akibat dari keputusan pemerintah menetapkan status kawasan hutan setelah masyarakat lebih dulu menempati wilayah tersebut. Menurut Hekmatyar et al. (2021), peningkatan fungsi kawasan taman nasional memang menguntungkan dari sisi konservasi, tetapi menjadi permasalahan pada sisi sosial ekonomi yaitu pembatasan pemanfaatan sumber daya alam oleh masyarakat. Pokok permasalahan di TNGL adalah mengenai hak-hak para pengungsi yang juga berstatus warga negara Indonesia di dalam konteks mereka mendiami lahan taman nasional.

\section{Kajian Pustaka}

Batlajery et al. (2018) mengatakan konflik agraria merupakan konflik yang tidak terhindarkan dalam pengelolaan sumber daya alam di Indonesia. Sebagai negara agraris, tanah merupakan sumber utama dalam berproduksi di Indonesia. Oleh sebab itu, hak kepemilikan, hak guna usaha, hak pakai, hak sewa, hak membuka tanah, dan hak memungut hasil hutan dibatasi dalam Undang-Undang Pokok Agraria (Adiansah et al., 2019).

Akar konflik agraria Indonesia bermula di era kemerdekaan tahun 1945. Konflik agraria setelah kemerdekaan muncul ketika para pemilik modal (kapitalis) diberi kekuasaan oleh pemerintah untuk menguasai tanah dalam jumlah besar. Salah satu contohnya adalah pemberian lahan kepada industri perkebunan oleh pemerintahan feodal di Langkat dan di negara bagian Sumatera Timur (Khairina et al., 2020). Sementara itu, rakyat kebanyakan hanya menjadi buruh di tanah-tanah yang di- 
kuasai oleh kapitalis (Zuber, 2013). Tatanan sistem konflik kapitalis ini masih mengakar di Indonesia dan diperlukan upaya ekstra untuk menghapuskannya.

Sylviani et al. (2014) menyebut bahwa konflik dalam kawasan hutan umum terjadi akibat tidak jelasnya hak-hak atau hukum yang berhubungan dengan sistem tenurial. Lund et al. (2018) dan Mccarthy et al. (2008) mengatakan bahwa pada kasus-kasus konflik tenurial, klaim pemerintah atas kekuasaan berdaulat terkait teritorial bersinggungan dengan klaim masyarakat lokal untuk hidup sesuai kebiasaan. Keduanya menegaskan dalam praktiknya, klaim atas properti dan kewarganegaraan saling terkait satu sama lain. Selain klaim yang absolut dan menyeluruh dari negara, perlu dipahami klaim parsial, pragmatis, tidak langsung (indirect) dalam perjuangan sumber daya alam agraria, penguasaan ruang dan pengakuan hak dari masyarakat.

Banyaknya klaim yang muncul dalam konflik tenurial menunjukkan bahwa yang diperebutkan bukan hanya lahan sebagai objek, tetapi juga legitimasi penguasaan lahan tersebut. Konflik ini biasanya berlangsung alot, lama, berkepanjangan dan sulit untuk diselesaikan karena memperebutkan justifikasi pihak tertentu untuk mengatur sistem kelola lahan dan pola kedudukan pihak lain di lahan tersebut (Muhammad et al., 2018).

Lund et al., (2018) mengembangkan konsep frontier atau perbatasan dan teritorialisasi menuju pengakuan. Perbatasan (frontier) sesungguhnya merupakan imajinasi sosial-politik dari sumber daya "bebas". Hal ini sangat tergantung pada penghapusan tanda-tanda klaim sebelumnya dan penghentian pengakuan dari klaim mereka (Peluso, 2006 dikutip oleh Hidayat, 2020). Konsep ini menjelaskan bahwa pengguna sumber daya dan otoritas melakukan berbagai klaim kontemporer dan tindakan pengakuan untuk mendapatkan kontrol spasial dan teritorialisasi.

Teritorialisasi didefinisikan oleh Oktayanty (2014) sebagai proses membagi suatu wilayah menjadi zona-zona politik ekonomi kompleks dan saling tumpang tindih yang akan membatasi pemanfaatan sumber dayanya. Teritorialisasi juga merupakan pilar utama kapitalisme yang sukses di banyak negara (Kelly, 2011; Lund et al., 2018). Proses tersebut menjadi upaya untuk penghancuran dan penghapusan tatanan sosial yang ada, mengaburkan dan menghilangkan hak pengelolaan sumber daya, hak milik dan kewarganegaraan serta kontrak sosial lainnya.

Tujuan dari teritorialisasi adalah memudahkan negara mengeklaim semua tanah yang tidak jelas kepemilikannya sebagai tanah negara, menetapkan batas tanah sebagai bentuk kontrol wilayah, lalu membagi wilayah tersebut ke dalam berbagai fungsi (Suryawan, 2021). Seperti teritorialisasi kawasan hutan sebagai kontrol negara dalam penggunaan sumber daya hutan, yang faktanya lebih banyak menguntungkan pihak korporasi daripada masyarakat (Budiono et al., 2018). Tentu jelas tergambar bahwa keadaan ini sangat merugikan masyarakat sebagai pihak yang tidak memiliki kuasa atas kontrol lahan yang telah dikelola.

Selama negara berusaha mengatakan atau menolak bahwa sekelompok masyarakat tidak memiliki hak di wilayah itu, maka ini adalah perbatasan (frontier). Pemerintah menciptakan ruang tanpa hukum di wilayah ini untuk melegitimasi upaya teritorialisasi yang dilakukannya. Hal ini menegaskan bahwa kontrol spasial dipengaruhi oleh hak properti dan kewarganegaraan (Lund, 2018; Lund et al., 2018). Kewarganegaraan yang dimaksud adalah keanggotaan badan politik yang terorganisir misalnya, Negara Indonesia, komunitas adat, atau keduanya menjadi kewarganegaraan dalam arti luas ketika keanggotaan dan haknya didukung dan ditegakkan. Perjuangan atas hak, identitas, kategori, melibatkan strategi legitimasi, visibilitas, transparansi dan tuntutan untuk pengakuan.

\section{Metode}

Studi ini dilakukan dengan metode kualitatif deskriptif. Peneliti menelusuri awal mula kedatangan pengungsi dari Aceh serta upaya 
dan strategi mereka dalam memperoleh akses legal dalam tata kelola Sumber Daya Alam (SDA) dan agraria di kawasan TNGL. Lokasi penelitian berada di tempat tinggal pengungsi Aceh yaitu Barak Induk, Damar Hitam, Sei Minyak dan Barak Gajah. Keempat lokasi terletak di dalam kawasan Taman Nasional Gunung Leuser (TNGL), Kabupaten Langkat, Provinsi Sumatera Utara.

Fieldwork untuk mengumpulkan data dilakukan kurang lebih empat bulan (Juli-November 2020). Teknik pengumpulan data dilakukan dengan cara wawancara dan observasi. Wawancara dilakukan secara informal terhadap pengurus Petani Indonesia pengungsi Aceh (PIPA) sebagai kelompok pengungsi. Observasi dilakukan terhadap kondisi pemukiman terkini pengungsi Aceh, kebun-kebun, fasilitas umum, serta potensi kondisi krisis agraria dan lingkungan yang mungkin terjadi di kawasan TNGL.

\section{Hasil dan Pembahasan}

\section{Identitas Politik dan Kependudukan Pengungsi Aceh}

Pengungsi Aceh merupakan identitas politik yang digunakan warga untuk melegitimasi keberadaannya di kawasan TNGL. Para pengungsi menempati dan mengelola zona inti yang telah berubah menjadi zona khusus di kawasan tersebut. Seharusnya secara politis, ketika masyarakat menerima dana terminasi, maka status sebagai pengungsi Aceh berubah menjadi eks pengungsi Aceh. Sayangnya dana ini sangat kecil sehingga warga tidak mampu untuk memulai kehidupan yang baru. Oleh karena itu, identitas politik sebagai pengungsi Aceh tetap dipertahankan dan digunakan. Apalagi tidak tersedia mekanisme penyelesaian yang jelas dan berkeadilan terkait hak-haknya sebagai pengungsi korban konflik politik. Upaya pengakuan negara terhadap keberadaan pengungsi Aceh selama 20 tahun juga belum ada. Pengungsi Aceh beraktivitas di pertanian seperti warga Langkat lainnya, tetapi secara politis keberadaannya belum dapat diterima.

Desa Harapan Maju adalah salah satu desa di
Kecamatan Sei Lepan, Kabupaten Langkat, Provinsi Sumatera Utara. Wilayah desa ini berada di batas kawasan TNGL. Pemerintah Desa Harapan Maju mengeluarkan kartu identitas berupa Kartu Tanda Penduduk (KTP) untuk pengungsi Aceh yang bermukim di wilayah Barak Induk.

Wilayah pemukiman pengungsi Aceh itu ditandai dengan gapura kampung yang menunjukkan keberadaan pangkal kampung Barak Induk. Namun, wilayah kelola pengungsi Aceh tidak bisa dilihat perbedaannya jika tidak ditanyakan kepada warga. Hal itu disebabkan wilayah ini yang tidak diakui sebagai bagian dari Desa Harapan Maju. Wilayah pemukiman mereka tidak masuk ke dalam peta desa dikarenakan wilayahnya yang beririsan dengan kawasan TNGL yang sudah lebih dulu ditetapkan. Oleh sebab itu, secara administrasi pengungsi Aceh belum diakui oleh pemerintah desa.

Pengungsi Aceh hanya mendapatkan KTP sebagai penanda identitas. Namun, mereka tidak pernah dilibatkan dalam pengambilan keputusan di tingkat pemerintah desa termasuk dalam pemilihan kepala desa (Pilkades). Selain itu, secara kewilayahan mereka tidak diakui dan tidak terdaftar dalam peta desa.

Pengungsi Aceh sebenarnya menyadari bahwa keberadaannya di wilayah kawasan TNGL menimbulkan permasalahan. Mereka juga menyadari bahwa mereka memiliki hak kelola, tetapi belum ada pengakuan terhadap keberadaannya. Oleh karena itu, sejak 2004, pengungsi Aceh terpaksa masuk dalam administrasi desa-desa sekitar seperti Desa Mekar Makmur dan Harapan Jaya.

\section{Kehidupan Pengungsi Aceh di Kawasan Taman Nasional Gunung Leuser}

Tahun 1996, Pemerintah Orde Baru telah mengosongkan areal konsesi beberapa perusahaan. Pembukaan kawasan hutan untuk perusahaan menunjukkan bahwa kawasan sudah dieksplorasi dan sebagian dijadikan pemukiman oleh masyarakat lokal yang bekerja untuk perusahaan tersebut. Awal mula 
masuknya pengungsi Aceh ke teritorial TNGL merupakan dorongan kelompok-kelompok masyarakat lokal yang tergabung dalam Koperasi Pratama. Mereka memberikan informasi kepada seorang tokoh pengungsi Aceh bernama Darmo untuk ikut mengelola lahan eks konsesi HPH, perusahaan yang berada di kawasan TNGL. Darmo sendiri merupakan anggota DPRD Kabupaten Langkat sekaligus sebagai Ketua Petani Indonesia pengungsi Aceh (PIPA) yang mengakomodir kebutuhan masyarakat. Masuknya pengungsi secara besar-besaran dalam rentang tahun 1999-2000, mengubah areal menjadi pemukiman dengan berdirinya gubuk-gubuk pengungsi, dan lahan yang ditanami palawija, ubi kayu, dan nilam.

Salah seorang warga bernama Misni yang tinggal di Barak Induk, bercerita telah datang bersama keluarganya sejak tahun 2000:

"Aku datang dari Rantau Panjang, Aceh. Saat itu ada selebaran yang dibagikan di sana untuk keluar dari Aceh Perlak. Istri saya orang Tanjung Pura dan saya tahu info di sini ada tempat ini dari orang dan pindahlah menetap di situ." - (Wawancara dengan Misni, 4 Mei 2020)

Selain Misni, ada juga informan lainnya bernama Anca yang kehilangan tempat tinggal akibat konflik dengan GAM. Di dalam wawancara dia menuturkan:

"Saya berasal dari Kuala Simpang, kemudian pindah ke Pekanbaru. Pemukiman kami dibakar di Aceh, saya datang kesini pada tahun 2000, saya menanam nilam di lahan Pak Sukardi/Darmo pun menikah di sini pada 2002-2003, saya menikah tahun 2003, lalu saya mendapat kaplingan dari Pak Sukardi dan membangun rumah tahun 2007. Sekarang sudah permanen sejak 2019." - (Wawancara dengan Anca, 4 Mei 2020)

Informan lain bernama Lily, pindah ke daerah Barak Itir sejak tahun 1999 bersama suaminya.
Ia juga merupakan korban konflik Aceh:

"Saya pindah ke sini sejak 1999, karena konflik Aceh dan saat itu rumah kami dibakar. Dulu saya tinggal bersama orang tua saya di Singkong Pitura, Aceh tahun 2000. Ada kabar dulu dari Pak Asbala. Ke sini saya ikut sama suami saya, dan mulai menetap sejak tahun 2001, mendirikan rumah disini. Untuk memenuhi kebutuhan hidup, kami mencari getah damar, lalu menanam karet." (Wawancara dengan Lily, 5 Mei 2020)

Berdasarkan wawancara, banyak juga pengungsi Aceh yang masuk ke wilayah TNGL dikarenakan ajakan dari teman yang telah tinggal dan memiliki mata pencaharian di kawasan ini.

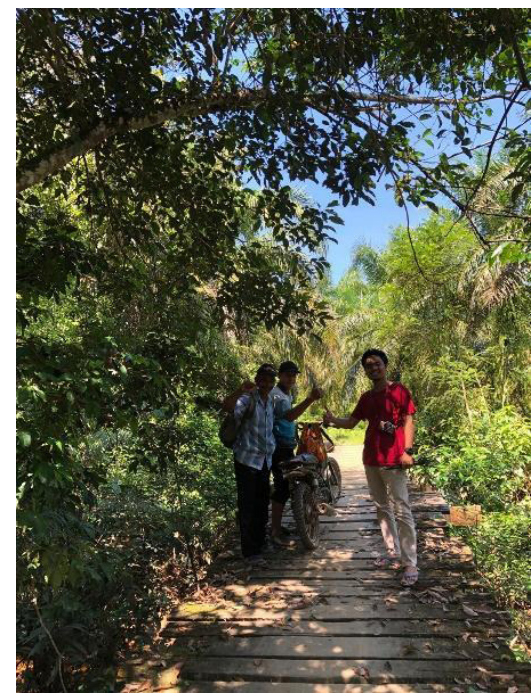

Gambar 1. Peneliti saat bersama dengan pengungsi Aceh

Sumber: Dokumentasi pribadi

Sebagai korban konflik politik, pengungsi Aceh harusnya memiliki hak kompensasi atas hilangnya properti yang mereka miliki di Aceh. Apalagi Pemerintah tidak mampu melindungi hak-hak atas keamanan properti pribadi dan rasa aman yang dijamin oleh UUD 1945. Namun, hingga kini tidak ada penyelesaian politik terhadap hal ini. Masyarakat hanya menerima uang kompensasi dari Dinas Sosial dan hilanglah statusnya sebagai pengungsi Aceh. 
Kehidupan awal pengungsi Aceh di TNGL sangat keras karena hasil budidaya palawija, padi darat, nilam, dan ubi kayu tidak dapat mencukupi kebutuhan hidup sehari-hari. Adanya kemarau panjang pada tahun 2001, turut menyebabkan kelangkaan pangan yang berujung musibah wabah penyakit. Situasi ini berlangsung sampai tahun 2006.

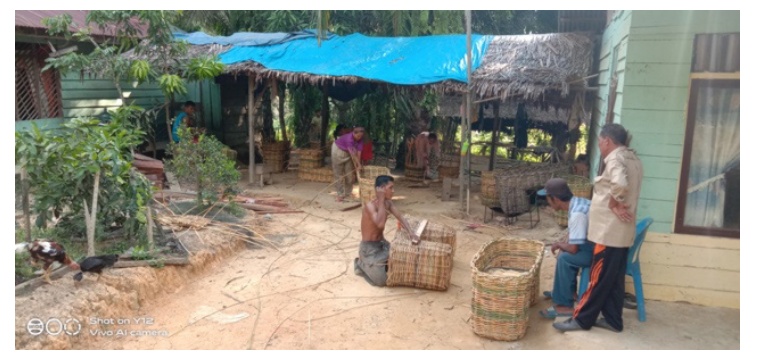

Gambar 2. Pengrajin Besek, salah satu sumber mata pencaharian dari Hasil Hutan Bukan Kayu (HHBK) pengungsi Aceh saat ini

Sumber: Dokumentasi pribadi

Situasi yang menyulitkan di areal pengungsi menyebabkan banyak pengungsi Aceh pindah dari wilayah ini. Mereka yang bertahan mencoba menambah penghasilan dengan mengumpulkan getah damar ke hutan dibantu oleh para istrinya. Selain itu, pengungsi Aceh juga bekerja menjadi pengrajin besek (lihat Gambar 2). Ada juga yang bekerja sebagai buruh harian kepada beberapa pengusaha kayu yang melakukan illegal logging di kawasan TNGL. Pekerjaan itulah yang menghadirkan stigma buruk sebagai "perambah" dari pihak manapun, baik pemerintah maupun masyarakat lokal sekitar.

Kesulitan yang dihadapi memaksa tokoh masyarakat di kalangan pengungsi Aceh untuk meminta bantuan. Berbagai donasi diperoleh termasuk bantuan donasi pemerintah. Pak Darmo/Sukardi dan Suyatno, adalah dua orang tokoh pengungsi yang turut meminta bantuan kepada berbagai pihak, seperti pemerintah, lembaga-lembaga gereja, dan Lembaga Swadaya Masyarakat (LSM). Banyak LSM dan lembaga gereja yang memberikan donasi dan bantuan kepada mereka. Namun program-program bantuan ini terhenti sejak tahun 2006 karena adanya bencana tsunami Aceh. Kondisi sulit ini juga kemudian membuat sebagian besar pengungsi Aceh menerima tawaran pemerintah untuk dipindahkan ke daerah lain. Kesulitan lain yang dihadapi adalah persoalan legalitas tanah. Persoalan ini menyangkut tempat tinggal dan tempat yang dikelola karena belum diakui secara sah. Pengungsi Aceh ibarat penghuni liar, kehilangan kewarganegaraan, dan tak memiliki hak-hak yang sama sebagaimana warga negara Indonesia pada umumnya.

\section{Hak-Hak Pengungsi Aceh sebagai Warga Negara}

Pengungsi Aceh sebagai bagian dari masyarakat Indonesia sudah seharusnya memperoleh hak-haknya sebagai warga negara. Hak mereka sebagai korban konflik Aceh tetap harus dipenuhi oleh pemerintah. Adapun hak-hak sebagai warga negara ini sudah jelas tertulis dan diatur dalam Undang-Undang Dasar 1945 sebagai konstitusi tertinggi yang harus ditaati oleh seluruh bangsa Indonesia. Hak yang dimiliki oleh pengungsi Aceh sebagai warga negara meliputi hak memperoleh persamaan kedudukan dalam hukum, hak untuk hidup dan mempertahankan kehidupan, hak untuk memperoleh pekerjaan, hak untuk menyuarakan pendapat, serta hak untuk memperoleh penghidupan yang layak. Hak-hak tersebut menjunjung tinggi nilai-nilai Hak Asasi Manusia (HAM) yang tidak boleh dilanggar.

Pengungsi Aceh justru mengalami berbagai kesulitan untuk memperoleh hak-haknya sebagai warga negara. Mereka telah mengelola lahan menjadi kebun palawija, lada dan tanaman lainnya, serta mengelola karet dan juga sawit selama 20 tahun untuk memenuhi kebutuhan sehari-hari. Rumah permanen sebagai tempat tinggal telah dibangun, termasuk membangun secara swadaya berbagai sarana dan prasarana seperti fasilitas umum, sekolah, masjid, lapangan olahraga, tempat pemakaman umum (TPU), dan jembatan. Namun, hak kelola dan kepemilikan lahan demi sumber penghidupan mereka yang telah dikelola selama 20 tahun, masih belum juga diakui oleh pemerintah. Hal inilah yang masih menjadi polemik dan harus segera diberikan solusi yang tepat oleh pemerintah. 
Pengungsi Aceh menghadapi dua konflik pengelolaan sumber daya yaitu: (1) konflik vertikal dengan BB-TNGL terkait eksklusi atas rekognisi keberadaan pengungsi Aceh di kawasan TNGL dan (2) konflik horizontal dengan Kelompok Pratama terkait double klaim pengelolaan di wilayah kelola yang sama. Kasus seperti ini sudah terjadi sebelumnya di Kalimantan seperti yang ditulis oleh Brosius (2006) bahwa narasi legal dan perambah yang diwacanakan pemerintah semakin menyudutkan posisi masyarakat adat atau masyarakat lokal, sedangkan akses terhadap pengakuan masih sulit mereka capai.

\section{Konflik Vertikal Antara Pengungsi Aceh dengan BB-TNGL}

Konflik pengelolaan sumber daya alam dan agraria semakin menguat di kawasan TNGL. Adanya perbedaan persepsi antara masyarakat lokal/adat dengan pemerintah merupakan salah satu penyebab utama adanya konflik tata batas di taman nasional (Purwawangsa, 2017). Keberadaan pengungsi Aceh di episentrum kawasan TNGL ibarat duri dalam daging bagi BB-TNGL. Di satu sisi terjadi perubahan tata ruang peruntukan, di sisi lain menjatuhkan otoritas dan wibawa BB-TNGL. Sementara itu, pengungsi Aceh yang membangun kehidupan baru pasca terusir dari Aceh, membutuhkan tanah untuk tempat tinggal dan bertani. Berbagai strategi untuk bertahan pun telah dilakukan.

BB-TNGL berkali-kali berusaha merelokasi dan mengusir pengungsi Aceh yang dicap sebagai "perambah". TNGL menganggap wilayah yang kini didiami oleh pengungsi Aceh adalah bagian area perbatasan (frontier) dalam otoritas kawasan TNGL Resort Sekoci-Besitang. Pengungsi Aceh tidak berhak atas wilayah ini.

Beragam teror, intimidasi bahkan upaya gusur paksa mencapai puncaknya pada 28 Juli 2011. TNGL berupaya menggusur paksa pemukiman Sei Minyak yang ditempati $40 \mathrm{KK}$ pengungsi Aceh sejak tahun 1999. Penggusuran ini bertujuan untuk mengantisipasi kerusakan hutan yang lebih parah. Sebelumnya pada 27 Juni 2011, sekitar 5.000 orang pengungsi Aceh berkumpul dan bersiap-siap sejak pagi. Pukul 12.30 WIB di persimpangan tower, mereka menghadang pasukan BB-TNGL yang membawa pasukan BRIMOBDA Sumatera Utara, Yonif 6 Marinir Tangkahan Lagan, Pasukan Raider 100 berkekuatan 400 personil dan lima ekor gajah, Polisi Pasukan Reaksi Cepat, Kodim 0203 Langkat, Polres Langkat, serta dua truk yang diisi 100 orang masyarakat lokal bayaran TNGL. Kepala Balai Besar TNGL Andi Basrul menyatakan keseluruhan personel berjumlah 1.200 personel.

Pengungsi Aceh dari Barak Induk, Sei Minyak dan Damar Hitam berkumpul, siap mati untuk mempertahankan 40 rumah di Sei Minyak. Solidaritas sebagai sesama pengungsi Aceh pun terbentuk. Tergusurnya Sei Minyak dipastikan akan menggusur pula Barak Induk dan Damar Hitam, sehingga wilayah itu harus dipertahankan. Upaya dialog antara pihak pengungsi Aceh dan pemerintah tidak berhasil dilakukan dan bentrokan keras pun terjadi.

Pada peristiwa ini, 9 pengungsi Aceh terkena luka tembakan dan 6 orang mengalami penganiayaan. Asmuri Simbolon, adalah korban dengan luka tembak terparah. Pasukan BB-TNGL menggunakan senjata gas air mata, peluru karet, peluru tajam, tameng dan pentungan. Peristiwa ini terpublikasi secara cepat dan mendapat protes keras dari masyarakat sipil baik di Indonesia maupun di luar negeri.

\section{Konflik Horizontal Antara Pengungsi Aceh dengan Kelompok Lokal}

Pengungsi Aceh juga mengalami konflik horizontal dengan warga sekitar. Konflik horizontal ini terjadi dengan warga yang tergabung dalam Kelompok Pratama dan Kelompok Manis Bangun.

Masuknya pengungsi Aceh ke kawasan TNGL disebabkan dekatnya wilayah ini dari tempat tinggal mereka. Didukung juga oleh adanya informasi tentang wilayah terbuka bekas perusahaan di dekat TNGL. Datangnya informasi itu berasal dari Kelompok Pratama. Diceritakan bahwa kelompok ini dipimpin oleh seorang Kolonel POLRI. Konflik dengan 
Kelompok Pratama dimulai pada tahun 2002, ketika pengungsi Aceh mulai menyadari adanya kepentingan oleh kelompok ini terhadap mereka. Kelompok Pratama mengeklaim kepemilikan seluruh wilayah yang ditempati dan dikelola pengungsi Aceh. Bahkan, Kelompok Pratama pernah menemui Gubernur Sumatera Utara dan Kementerian Kehutanan untuk memohon pelepasan kawasan atau enklave atas wilayah yang pengungsi Aceh tempati dan kelola seluas 4.780 ha dari areal TNGL. Padahal faktanya tidak ada anggota koperasi Kelompok Pratama yang menduduki dan mengelola tanah pengungsi Aceh. Pengungsi Aceh juga menuturkan bahwa pernah dimanfaatkan sebagai pekerja penebang kayu atas inisiatif Kelompok Pratama.

Selanjutnya di tahun 2004, pengungsi Aceh menyadari secara kolektif bahwa mereka juga dimanfaatkan oleh kelompok lain bernama Manis Bangun. Kelompok Manis Bangun tetap berusaha mengeklaim dan menguasai keseluruhan tanah yang dikelola oleh pengungsi Aceh. Akibatnya timbul jarak antara warga pengungsi Aceh dengan Kelompok Pratama dan Manis Bangun.

\section{Strategi Legalisasi Pengungsi Aceh untuk Mendapatkan Hak}

Pengungsi Aceh di Barak Induk, Sei Minyak dan Damar Hitam mengembangkan beragam legalisasi untuk menguasai lahan yang telah dikelola selama 20 tahun. Beragam strategi dikembangkan baik dalam bentuk klaim langsung (direct claim) maupun klaim tidak langsung (indirect claim). Hal ini memperlihatkan perubahan dari kondisi tidak legal menjadi seperti legal. Merujuk pada Khairina et al. (2020), masyarakat menciptakan fakta-fakta legal dan mencoba menjadi terlihat legal dengan berbagai bentuk upaya. Upaya yang paling visioner adalah diproduksinya peta wilayah kelola pengungsi Aceh sebagai bagian birokrasi untuk mendokumentasikan keberadaannya.

Berbagai upaya legalisasi merupakan wujud dari perjuangan petani yang dikemukakan oleh Moore (1998). Kebijakan pengembangan taman nasional menyebabkan perselisihan antara petani dan negara. Perselisihan itu membentuk kesadaran bagi petani untuk memperjuangkan haknya yang dikenal sebagai forest dependent people, yaitu memanfaatkan hutan tidak hanya sebagai sumber energi tetapi juga sebagai tempat hidup. Kebutuhan tersebut menjadi pemicu masyarakat untuk melakukan perlawanan (Purwanto, 2014).

Meskipun tidak dibantu oleh negara dan dianggap sebagai perambah oleh BB-TNGL, kemandirian pengungsi Aceh selama sekitar 20 tahun terakhir telah menjadikan wilayah ini layak disebut sebagai sebuah desa yang legal. Nasib dan latar belakang yang sama menjadi sebab menguatnya solidaritas antar mereka untuk berjuang. Mereka berhasil menguasai dan mengelola sekitar 4.000 ha tanah di area klaim BB-TNGL Besitang. Jumlah ini lebih kecil dari klaim TNGL bahwa terdapat 6.800 ha kawasannya yang mengalami kondisi kritis dan dikuasai oleh perambah.

Adapun beragam strategi legalisasi yang telah dilakukan ialah dengan mengirimkan kader pengungsi Aceh sebagai anggota DPRD periode 2019-2024; membangun berbagai fasilitas sarana dan prasarana bagi kepentingan umum; memperkenalkan identitas pengungsi Aceh melalui jalur kesenian dari panggung ke panggung; serta membentuk organisasi PIPA (Petani Indonesia Pengungsi Aceh) sebagai wadah mereka memperjuangkan pengelolaan hak atas tanah dan ekonomi yang telah mereka kelola selama ini.

\section{Mengirim Kader Menjadi Anggota DPRD}

Petani Indonesia Pengungsi Aceh (PIPA) mendorong ketuanya, yakni Darmo alias Sukardi, untuk maju sebagai kontestan pemilihan calon legislatif (CALEG) di Kabupaten Langkat melalui Partai Nasional Demokrat (NasDem). Mendapat nomor urut 2, Darmo berjuang mewakili Daerah Pemilihan (DAPIL) 5 yaitu Sei Lepan, Besitang, Pematang Jaya, Pangkalan Susu, Brandan Barat dan Babalan. Upaya ini dilakukan untuk mewujudkan harapan masyarakat pengungsi Aceh untuk legalisasi wilayah mereka. 
Darmo membawa slogan Wes Wayahe, atau yang artinya "sudah masanya" untuk maju ke Pemilihan Legislatif (PILEG) 2019. Makna slogan ini yang menggerakkan warga dengan sukarela memilih Darmo untuk maju ke PILEG 2019. "Sudah masanya" bisa bermakna beragam, seperti sudah masanya pengungsi Aceh maju ke panggung politik dan sudah masanya orang Jawa dari Barak Induk sekitarnya maju ke kancah politik memperjuangkan hak-haknya.

\section{Membangun Fasilitas}

Tidak hanya dimanfaatkan sebagai lahan perkebunan, Kawasan TNGL juga dimanfaatkan pengungsi Aceh untuk membangun berbagai fasilitas umum. Fasilitas umum yang dibangun seperti jalan, jembatan, lapangan olahraga, tempat penimbangan getah karet dan Tempat Pemakaman Umum (TPU). Selain itu, dibangun juga sekolah bagi anak-anak pengungsi Aceh (lihat Gambar 3) dan fasilitas sosial seperti masjid (lihat Gambar 4) dan puskesmas secara swadaya di tiga wilayah ini. Beragam bangunan ini dapat dimanfaatkan untuk kepentingan bersama.

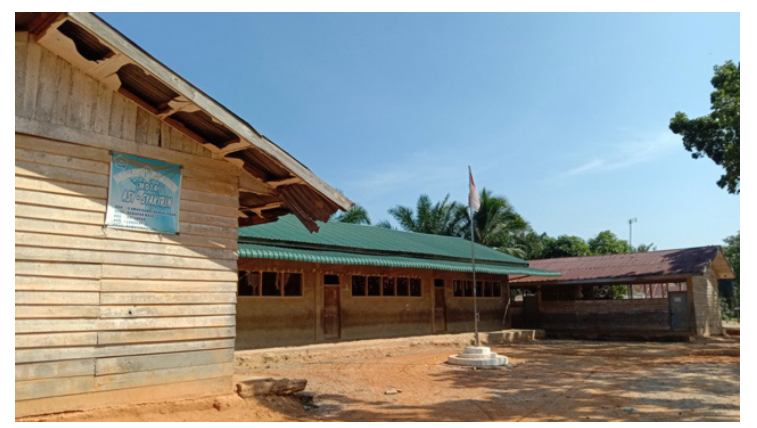

Gambar 3. Madrasah/Sekolah Dasar di Barak Induk

Sumber: Dokumentasi pribadi

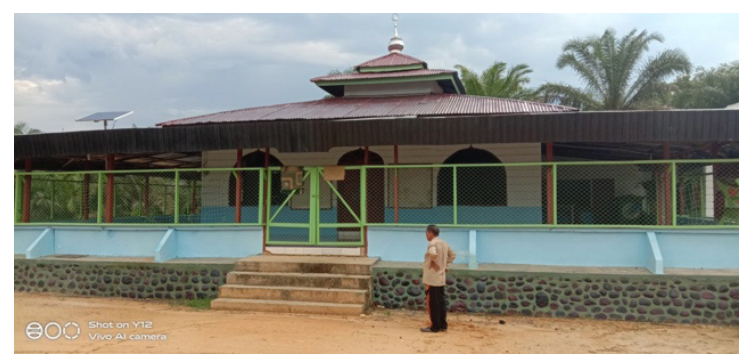

Gambar 4. Masjid di Barak Induk

Sumber: Dokumentasi pribadi
Pengungsi Aceh mendapatkan stigma "perambah" dari pemerintah dan masyarakat sekitar. Melalui PIPA, pengungsi Aceh menginisiasi pembentukan kelompok seni untuk melawan stigma tersebut. Kelompok seni ini melibatkan perempuan pengungsi Aceh dan tampil di panggung acara pemerintah lokal sampai nasional. Mereka mengkampanyekan bahwa "Warga Pengungsi Aceh Bukan Perambah". Di akhir tahun 2005, pihak BB-TNGL melakukan pertemuan dialog bersama pengungsi Aceh membahas lokasi yang dikelola pengungsi Aceh. Namun, dialog itu belum menghasilkan keputusan selain kesepakatan untuk dialog lanjutan.

\section{PIPA sebagai Interest Group Pengungsi Aceh}

Pengungsi Aceh mengorganisir dirinya dalam organisasi Petani Indonesia Pengungsi Aceh (PIPA). Awalnya PIPA bernama PPA (Petani Pengungsi Aceh) yang dibentuk pada tahun 2000 ketika awal mereka memasuki barak yang berada di kawasan TNGL. Ketua pengurus harian PPA yang pertama bernama Tumin dan majelis pertama adalah Komaruddin. Pada tahun 2001, PPA berganti nama menjadi Petani Indonesia Pengungsi Aceh (PIPA) sekaligus membentuk struktur kepengurusan yang baru. Kepengurusan PIPA terdiri dari Dewan Majelis dan Badan Pengurus Harian (BPH). Pada tahun 2005, organisasi ini baru resmi didaftarkan dan disahkan ke notaris serta mendapatkan Akta Notaris pertamanya. Setelah menjadi PIPA, Sukardi alias Darmo terpilih sebagai pimpinan BPH PIPA. Sementara majelis PIPA dipimpin oleh Suyatno sejak 2012. Seharusnya setiap 3 tahun sekali dipilih kepengurusan baru, tetapi hingga saat ini belum ada terjadi perubahan kepengurusan.

PIPA menjadi wadah perjuangan pengungsi Aceh untuk mengatur pengelolaan lahan, ekonomi, dan sistem administrasi pengungsi Aceh yang berada di setiap lorong Barak Induk, Barak Seng, Barak Itir, dan Barak Kentong. Keseluruhan pengaturan ini merupakan tanggung jawab Darmo sebagai Ketua PIPA. 
PIPA juga menjadi wadah penyelesaian masalah di kalangan pengungsi Aceh. Mekanisme ditempuh dengan cara musyawarah mufakat. Apabila terjadi perselisihan, masalah akan diselesaikan oleh kepala lorong masing-masing barak. Apabila tidak dapat diselesaikan, maka perselisihan diselesaikan oleh Ketua PIPA. Menurut Suyatno, anggota pengungsi Aceh sudah sadar terhadap situasi politik di tempat mereka. Mereka memahami bahwa status mereka di pemerintahan desa belum diakui, sehingga penyelesaian perselisihan tidak akan mungkin dibawa ke ranah pemerintah desa. Berbagai upaya legalisasi yang dilakukan tersebut belum menunjukkan hasil hingga saat ini. Pengungsi Aceh belum mendapatkan pengakuan klaim wilayah dan teritorial yang telah dibangun. Sampai saat ini status mereka masih dianggap sebagai perambah hutan konservasi dan belum mendapatkan kepastian hukum dari negara tentang keberadaannya.

\section{Resolusi Konflik Agraria bagi Pengungsi Aceh}

Pada masa Orde Baru, pemerintah menyelesaikan permasalahan pengelolaan agraria dengan menjadikan negara penguasa absolut atas sumber daya agraria. Solusi ini muncul akibat peristiwa politik pada 1965 yang menyebabkan Pemerintahan Orde Baru mengaburkan ruh Undang-Undang Pokok Agraria. Pada 1967, Pemerintahan Orde Baru membuat Undang-Undang Penanaman Modal Asing (UUPMA) Nomor 1 Tahun 1967 yang menjadi gerbong bagi masuknya investasi atau modal asing besar-besaran (Luthfi et al., 2010; Khairina, 2013). Izin-izin kuasa dan pengelolaan tanah untuk investor yang diberikan Pemerintahan Orde Baru telah mengubah secara total arah pembangunan Indonesia. Termasuk tidak terlaksananya land reform dan arah pembangunan yang mengarah kepada pembukaan investasi besar-besaran.

Pendekatan yang dilakukan Pemerintahan Orde Baru dalam menangani konflik sumber daya alam dan agraria selalu menggunakan pendekatan kekerasan, hegemonik dan militeristik. Dengan pola hegemonik, masyarakat adat, petani dan petani penggarap yang umumnya tidak memiliki alat bukti, selalu dikalahkan dalam proses hukum. Situasi ini relevan dengan konsep akses yang dirumuskan Ribot et al. (2003) dan Abdurrahim (2015) bahwa akses diartikan sebagai kemampuan untuk memiliki kekuasaan dalam memanfaatkan dan mengontrol sumber daya.

Kawasan Taman Nasional Gunung Leuser sendiri baru diresmikan pada tahun 1980 melalui Pengumuman Menteri Pertanian Nomor $881 / \mathrm{Kpts} / \mathrm{UM} / 1980$. Peresmian ini menjadi langkah perlindungan kawasan dan satwa liar sekaligus jalan bagi negara untuk mengontrol akses terhadap sumber daya di kawasan TNGL. Akibatnya terjadi pola perubahan penguasaan terhadap akses sumber daya yang menimbulkan permasalahan legal akses bagi masyarakat. Hak-hak penggarap tradisional dan warga atas nama masyarakat hukum adat Kedatukan Besitang pun mulai terpinggirkan. Adanya sistem zonasi pada TNGL juga diyakini akan membatasi masyarakat secara ketat untuk memanfaatkan sumber daya alam lokal yang telah menjadi tradisi di kawasan tersebut. Pembatasan ini akan menimbulkan konflik berkepanjangan (Negara, 2011).

TNGL sebagai taman nasional dipandang sebagai objek yang "belum membumi". Dikatakan seperti itu karena masyarakat lokal di Indonesia tidak memahami dengan sepenuhnya fungsi dan peranan sebuah taman nasional (Indriyo, 2002). Kontrol negara dalam hal ini sangat penting untuk mencegah konflik tenurial. Negara diperlukan sebagai pemegang kontrol yang memiliki kekuatan hukum tetap untuk mengambil keputusan yang tepat dengan tidak mengabaikan hak-hak masyarakat sebagai warga negara.

Di dalam permasalahan pengungsi Aceh dan TNGL, penetapan kawasan menjadi kawasan konservasi justru sering menciptakan konflik. Seharusnya konflik tersebut tidak akan terjadi apabila pengetahuan lokal masyarakat telah memiliki nilai-nilai konservasi. Dengan begitu, masyarakat dapat melakukan perlindungan keanekaragaman hayati dengan mandiri, dan 
pemerintah tidak perlu meminggirkan masyarakat lokal yang sudah terlebih dahulu menempati kawasan tersebut (Negara, 2011). Apalagi pengungsi Aceh hanya mengelola kurang lebih 4.000 ha dari total $830.268,95$ ha luas area. Seharusnya pemerintah tidak mengabaikan hak-hak pengungsi Aceh atas apa yang telah mereka kelola selama 20 tahun. Mereka juga tetap memperhatikan keberlanjutan ekologis kawasan TNGL. Pendekatan berbasis hak dalam pengelolaan kawasan TNGL berdasarkan prinsip keadilan dan berkelanjutan penting untuk dilakukan, selaras dengan pemenuhan nilai-nilai hak asasi manusia.

Pengelolaan kawasan TNGL harusnya juga mempertimbangkan kondisi para pengungsi sebagai korban dari konflik negara. Terlebih kondisi mereka pasca-konflik sangat memprihatinkan. Akibat konflik, mereka banyak kehilangan anggota keluarga, pekerjaan, tempat tinggal dan terpaksa harus mengungsi. Ketidakmampuan pemerintah menangani persoalan pasca-konflik berpotensi melanggar hak asasi manusia para pengungsi (Mukhlis et al., 2021)

Berbagai upaya yang dilakukan oleh pemerintah untuk meminimalisir dan menghentikan sengketa ini masih belum optimal. Agar permasalahan ini dapat diselesaikan, diperlukan upaya yang solutif dari pemerintah dan juga berbagai pemangku kepentingan (stakeholder) terkait. Upaya resolusi konflik yang ada bisa melalui pihak eksternal sebagai wadah bagi pengungsi Aceh. Pihak eksternal dibutuhkan agar dapat menjembatani berbagai keinginan mereka, seperti organisasi gerakan lingkungan Wahana Lingkungan Hidup (Walhi). Walhi dapat membantu untuk mendorong pengakuan dan legalisasi keberadaan masyarakat pengungsi di kawasan TNGL. Penguatan dan pemberdayaan ekonomi berbasis wilayah kelola bagi rakyat yang berstatus pengungsi, serta penguatan dan pemberdayaan perempuan pengungsi dalam pengelolaan sumber daya alam dan agraria.

Pemerintah juga dapat memberikan hak pakai bagi pengungsi dalam jangka waktu tertentu. Selain itu, memberikan dana terminasi dengan tetap memperhatikan apa yang menjadi hak- hak pengungsi sebagai warga negara. Lalu melakukan pendekatan berbasis hak dalam pengelolaan kawasan TNGL, termasuk juga melakukan upaya pengakuan wilayah kelola oleh pengungsi. Pengakuan dilakukan dengan prinsip keadilan dan berkelanjutan dalam rangka memenuhi keberlangsungan hidup mereka sebagai warga negara.

\section{Simpulan}

Pengungsi Aceh mulai masuk ke wilayah kawasan Taman Nasional Gunung Leuser (TNGL) pada 1999 setelah pemberlakuan Daerah Operasi Militer (DOM) di Aceh akibat konflik. Mereka membangun pemukiman dan mengelola sekitar 4000 ha kawasan TNGL sebagai sumber mata pencaharian. Konflik agraria yang terjadi antara pengungsi Aceh dengan pihak pengelola Balai Besar-TNGL, dan juga dengan Kelompok Pratama dan Kelompok Mulia Bangun telah menimbulkan berbagai polemik yang harus segera ditangani.

Berbagai strategi legalisasi berkaitan dengan upaya mendapat hak pengelolaan lahan di TNGL telah dilakukan pengungsi Aceh. Misal, ada pengungsi Aceh yang menjadi anggota DPRD periode 2019-2024; dibangunnya berbagai sarana dan prasarana bagi kepentingan umum; penguatan eksistensi pengungsi Aceh melalui jalur kesenian dari panggung ke panggung; serta dibentuknya PIPA (Petani Indonesia Pengungsi Aceh) sebagai wadah dalam memperjuangkan hak pengelolaan lahan dan ekonomi.

Dinamika perbatasan yang keras di kawasan TNGL telah menyebabkan beragam ancaman yang dialami pengungsi Aceh oleh negara. Ancaman seperti intimidasi, teror, stigma "perambah", penganiayaan, penembakan, relokasi, penggusuran paksa pemukiman, kriminalisasi dan embargo menutup sumber pasokan pangan ke wilayah ini. Selain itu, juga ditutupnya akses pasar hasil kebun dari wilayah ini. Semua ancaman tersebut telah menempatkan mereka menjadi korban berlapis pasca terusir dari Aceh. 
Konflik tenurial yang mengancam penurunan kualitas dan kuantitas kawasan TNGL hanya bisa diselesaikan jika adanya kolaborasi berbagai pihak. Upaya yang dapat dilakukan seperti kerja sama ataupun kemitraan antara masyarakat yang sudah menduduki kawasan tersebut dengan pemerintah (daerah dan pusat), NGO, perusahaan swasta dan lainnya. Apabila upaya ini dilakukan secara berkelanjutan, maka akan menjadi win-win solution dan lebih menjamin peningkatan dan pelestarian nilai alam dan budaya TNGL, serta memberikan kesejahteraan bagi pengungsi Aceh. Ancaman terhadap hilangnya nilai-nilai konservasi, menurunnya fungsi ekosistem, dan meluasnya perambahan di kawasan TNGL dapat diminimalisir.

\section{Referensi}

Abdurrahim, A. Y. (2015). Skema Hutan Kemasyarakatan (HKM) Kolaboratif sebagai Solusi Pengelolaan SDA di Hutan Sesaot, Lombok Barat. Jurnal Sosiologi Pedesaan, 3(3), 91-100. https://doi.org/10.22500/sodality.v3i3.10639

Adiansah, W., Apsari, N. C., dan Raharjo, S. T. (2019). Resolusi Konflik Agraria di Desa Genteng Kecamatan Sukasari Kabupaten Sumedang. Jurnal Kolaborasi Resolusi Konflik, 1(1), 1-70. https://doi.org/10.24198/ jkrk.v1i1.20887

Batlajery, A., Pattiselanno, A. E., dan Kakisina, L. O. (2018). Konflik Agraria di Desa Watmuri Kecamatan Nirunmas Kabupaten Maluku Tenggara Barat. Agrilan: Jurnal Agribisnis Kepulauan, 5(2), 88-100. https://doi. org/10.30598/agrilan.v5i2.157

Brosius, J. P. (2006). Common Ground between Anthropology and Conservation Biology. Conservation Biology, 20(3), 683-685. https://www.jstor.org/stable/3879230

Budiono, R., Nugroho, B., dan Nurrochmat, D. R. (2018). Dinamika Hegemoni Penguasaan Hutan di Indonesia. Jurnal Analisis Kebijakan Kehutanan, 15(2), 113-126. https://doi. org/10.20886/jakk.2018.15.2.113-126

Darmawan, A. (2020). Arena Sosial, Petani, dan Perluasan Konflik Pertanahan di Sumatera Utara. Jurnal Antropologi: Isu-Isu Sosial Budaya, 22(02), 246-255. https://doi. org/10.25077/jantro.v22.n2.p245-255.2020

Harnadi, K. (2019). Model Penguasaan Tanah oleh Masyarakat Desa Margosari dan Penyelesai- annya pada Kawasan Hutan Lindung Register 22 Way Waya Kabupaten Pringsewu. $\mathrm{Ce}$ palo, 2(2), 85-92. https://doi.org/10.25041/ cepalo.v2no2.1765

Hekmatyar, V., dan Adinugraha, A. G. (2021). Ancaman Keberfungsian Sosial pada Masyarakat di dalam Kawasan Konservasi: Studi Kasus Desa Ranupani di Taman Nasional Bromo Tengger Semeru. BHUMI: Jurnal Agraria dan Pertanahan, 7(1), 28-41. https://doi. org/10.31292/bhumi.v7i1.464

Hidayat, R. (2020). Politik Teritorial dan Perampasan Tanah-Hutan di Desa Lingkar Tambang Bijih Besi, Kecamatan Lede, Kabupaten Taliabu, Provinsi Maluku Utara. Emik, 3(1), 1-16. https://doi.org/10.46918/emik.v3i1.491

Kaputra, I., dan Putri, P. W. (2020). The Precarity of Peri-urban Resistance: A Resistance to the Forced Eviction of Pasar VI Village and the Development of Kualanamu International Airport, North Sumatera. PCD Journal, 8(1), 49-67. https://doi.org/10.22146/pcd. v8i1.419

Kaputra, I., Siregar, T. R., dan Sinaga, W. K. (2015). Petani Kehilangan Tanah: Strategi legalisasi Perjuangan Kasus Konflik Agraria di Desa Pergulaan, Kec. Sei Rampah, Kab. Serdang Bedagai, Sumatera Utara. Di dalam Burung-burung Kehilangan Sarang: Kisah Tiga Kampung dalam Konflik Agraria. Yogyakarta: Pustaka Sempu.

Kelly, J. L. (2011). ANew Interpretation of Information Rate. World Scientific, 3, 25-34. https:// doi.org/10.1142/9789814293501_0003

Khairina, W. (2013). Konflik Agraria Masyarakat Desa Pergulaan vs PT. PP London Sumatera Indonesia Tbk. Kab. Serdang Bedagai, Sumatera Utara. Skripsi. Universitas Negeri Medan.

Khairina, W., dan Lund, C. (2020). Creating Legal Facts: Indigenous People versus State Plantation Companies in Medan, Indonesia. PCD Journal, 8(1), 1-12. https://doi. org/10.22146/pcd.v8i1.417

Lund, C. (2018). Predatory peace. Dispossession at Aceh's oil palm frontier. The Journal of Peasant Studies, 45(2), 431-452. https://doi. org/10.1080/03066150.2017.1351434

Lund, C., dan Rachman, N. F. (2018). Indirect Recognition. Frontiers and Territorialization around Mount Halimun-Salak National Park, Indonesia. World Development, 101, 417-428. https://doi.org/10.1016/j.worlddev.2017.04.003 
Luthfi, A. N., Tohari, A., dan Nugroho, T. (2010). Pemikiran Agraria Bulaksumur (M. Prof. Dr. Endriatmo Soetarto (ed.)). Yogyakarta: STPN Press.

Mccarthy, J. F., dan Warren, C. (2008). Communities, Environments and Local Governance in Reform Era Indonesia. Di dalam Community, Environment and Local Governance in Indonesia (1st ed., hal. 26). Routledge. https://doi.org/10.13140/2.1.1313.8560

Moore, D. S. (1998). Subaltern Struggles and the Politics of Place: Remapping Resistance in Zimbabwe's Eastern Highlands. Cultural Anthropology, 13(3), 344-381. https://doi. org/10.1525/can.1998.13.3.344

Muhammad, F., dan Paskarina, C. (2018). Relasi Kuasa dalam Perebutan Lahan di Situs Candi Bojongmenje. Umbara, 2(1), 45-55. https:// doi.org/10.24198/umbara.v2i1.15678

Mukhlis, M., dan Manan, A. (2021). Peran Pemerintah terhadap Masyarakat Korban Konflik dan Kondisi Kehidupan Sosial Pasca Damai. Al-Ijtima i: International Journal of Government and Social Science, 6(2), 115-126. https://doi.org/10.22373/jai.v6i2.776

Negara, P. D. (2011). Rekonstruksi Kebijakan Pengelolaan Kawasan Konservasi Berbasis Kearifan Lokal sebagai Kontribusi Menuju Pengelolaan Sumber Daya Alam yang Indonesia. Jurnal Konstitusi, 4(2), 91-138.

Nuraini, A., Aziz, D. A. N., Cahyono, E., dan Moniaga, S. (2016). Ringkasan Temuan dan Rekomendasi untuk Perbaikan Hukum dan Kebijakan tentang Penghormatan, Perlindungan, Pemenuhan dan Pemulihan Hak Masyarakat Hukum Adat atas Wilayahnya di kawasan Hutan. Di dalam Paper Knowledge: Toward a Media History of Documents (hal. 12-26). Jakarta: Komisi Nasional Hak Asasi Manusia Republik Indonesia.

Oktayanty, Y. (2014). Dari Hutan Adat Kalawa ke Hutan Desa: Sebuah Teritorialisasi Negara Berbasis Masyarakat? Jurnal Antropologi: Isu-Isu Sosial Budaya, 16(1), 83-97. https:// doi.org/10.25077/jantro.v16i1.20

Pelzer, K. J. (1985). Toean Keboen dan Petani. Jakarta: Penerbit Sinar Harapan.

Purwanto, S. A. (2014). Taman Nasional, Hak-Hak Masyarakat Setempat dan Pembangunan Regional. Antropologi Indonesia, 29(3), 269288. https://doi.org/10.7454/ai.v29i3.3546

Purwawangsa, H. (2017). Instrumen Kebijakan untuk Mengatasi Konflik di Kawasan $\mathrm{Hu}-$ tan Konservasi. Risalah Kebijakan Pertani- an dan Lingkungan, 4(1), 28-47. https://doi. org/10.20957/jkebijakan.v4i1.20059

Ribot, J., dan Peluso, N. (2003). A Theory of Access. Rural Sociology, 68, 153-181. https://doi.org/10.1111/j.1549-0831.2003. tb00133. $\mathrm{x}$

Robbins, P. (2019). Political Ecology: A Critical Introduction. Wiley. Retrieved from https://books.google.co.id/books?id=nOGvDwAAQBAJ

Robbins, Paul, dan Monroe Bishop, K. (2008). There and Back Again: Epiphany, Disillusionment, and Rediscovery in Political ecology. Geoforum, 39(2), 747-755. https:// doi.org/https://doi.org/10.1016/j.geoforum.2006.12.013

Sudirman, A., dan Haryanto, N. N. (2018). Upaya Disaster Diplomacy Pemerintah Indonesia di Konflik Aceh Tahun 2005. Ilmu-Ilmu Sosial dan Humaniora, 20(3), 269-276. https://doi. org/10.24198/sosiohumaniora.v20i3.15586

Suryawan, I. N. (2021). Memperjuangkan Sumber Kehidupan Sesungguhnya: Masyarakat Adat Dalem Tamblingan dan Kedaulatan atas Alas Merta Jati di Kabupaten Buleleng, Bali. Bhumi: Jurnal Agraria dan Pertanahan, 7(1), 79-95. https://doi.org/10.31292/ bhumi.v7i1.479

Sylviani, S., dan Hakim, I. (2014). Analisis Tenurial dalam Pengembangan Kesatuan Pengelolaan Hutan $(\mathrm{KPH})$ : Studi Kasus KPH Gedong Wani, Provinsi Lampung. Jurnal Penelitian Sosial dan Ekonomi Kehutanan, 11(4), 309-322. https://doi.org/10.20886/ jpsek.2014.11.4.14

Tim Inkuiri Nasional Komnas HAM. (2016). Buku I: Hak Masyarakat Hukum Adat atas Wilayahnya di Kawasan Hutan.

Zainal, S. (2016). Transformasi Konflik Aceh dan Relasi Sosial-Politik di Era Desentralisasi. MASYARAKAT: Jurnal Sosiologi, 21(1), 81108. https://doi.org/10.7454/mjs.v21i1.4757

Zuber, A. (2013). Konflik Agraria di Indonesia. Sosiologi Reflektif, 8(1), 147-158. 